\title{
From Mori Akira to Narrative Education: Weaving the Tapestry of Narrative Philosophy, Analysis, Therapy, Pedagogy, and Research
}

\author{
Anton Sevilla-Liu ${ }^{1}$ (D)
}

Received: 21 October 2020 / Revised: 18 February 2021 / Accepted: 21 February 2021 /

Published online: 13 March 2021

(C) The Author(s), under exclusive licence to Springer Nature Switzerland AG part of Springer Nature 2021

\begin{abstract}
The narrative approach has developed in various directions-philosophy, qualitative analysis, therapy, pedagogy, and research methodology—but these various directions are often isolated from each other. This article weaves together these five threads of narrative in order to suggest a novel way for how narrative can be used in the classroom. This is done through narratively expressed action research (Jean Clandinin) on the experiences of the author, a university teacher in Japan, and his attempts to incorporate narrative elements into career education classes. This article begins with its theoretical foundations, the narrative philosophy of education of Mori Akira, and how it was applied to pedagogically support the growth of self-awareness S1 (social identity) in a university orientation class. It then explores the design principles of this class, drawing from Dan P. McAdams's narrative analysis and modified using narrative therapy (Michael White \& David Epston). Next, it narrates the teacher's experience of reading and responding to students' narratives in two parts: the first five sessions where students write autobiographical exercises (looking at the "authored self") and the last two sessions where students reflect on the texts they have written (highlighting the "authoring self"). I conclude with several design principles that seek to weave together narrative pedagogy, analysis, and therapy.
\end{abstract}

Keywords Japanese philosophy $\cdot$ Kyoto School $\cdot$ Narrative analysis $\cdot$ Narrative therapy

Narrative is a process of weaving together the disparate experience of our lives into a tapestry that is meaningful. The fabric of our human understanding of narrative has various threads. Narrative is of course studied in literature, which has its own tradition of analysis and hermeneutics. There is narrative philosophy, such as that by Paul Ricoeur; narrative psychology, as in the well-cited Jerome Bruner; Dan P. McAdams (1997a, this was simultaneously but independently from Bruner) developed narrative as a method of qualitative analysis, combining both idiographic and nomothetic approaches to the life story; Michael White and David Epston developed narrative as an approach to psychotherapy

Anton Sevilla-Liu

asevilla@gmail.com

1 Kyushu University, Fukuoka, Japan 
and community work, drawing heavily from anthropological approaches to narrative; Ivor Goodson and Scherto Gill $(2010,2014)$ developed the idea of narrative pedagogy, drawing heavily from sociological approaches to life stories; and Jean Clandinin developed narrative as a form of research-narrative inquiry. These are but the thickest strands in this complex fabric!

However, I cannot escape the sense that this fabric, for all its emphasis on weaving together, remains frayed. While many cite Ricoeur and Bruner (see Langdridge, 2007), the relationship between psychology and philosophy tends to be one-way, and from my own experience, it is difficult to cite psychology in philosophy journals. Furthermore, conversation between narrative analysis and narrative therapy is scant, despite similarities between analysis and case conceptualization in therapy and despite some preliminary work by McAdams' own team (see McAdams \& Janis, 2004). Narrative pedagogy has much to learn from narrative therapy, and there is work on narrative counseling in schools that actively seek to transform school culture as a whole (Winslade \& Monk, 2006), but it remains difficult to find research on how to use narrative therapy in a non-therapeutic context such as in the classroom (for some exceptions in Japan, see Kojima and Sugita, 2014; Saitô, 2003) . Narrative inquiry also does not make adequate use of the rich structural analysis tools of narrative psychology. This fraying is not necessarily a matter of negligence-there may be core methodological and philosophical differences that confound dialogue.

In this article, I attempt to weave together these loose ends in order to show how narrative can come to life in the classroom. I will do this through narrative inquiry (Clandinin $\&$ Connelly, 2004) on my own journey to narrative pedagogy_from designing, teaching, and responding to a narrative career education class in Japan. This journey combines (Japanese) narrative philosophy of education, analysis, and therapy in a pedagogical context. While this (like all narratives) is but one way of weaving together this complex tapestry, I hope it suggests how conversations might be pulled together in the future.

In this article, I will begin by introducing Mori Akira - the philosopher of education on whom I based my idea of narrative pedagogy - and my journey from his philosophy toward an actual practice of narrative pedagogy that goes through narrative analysis and therapy. Then, I will detail my action research on university orientation classes I conducted at a Japanese university. I will narrate the process of designing the class, the experience of teaching it, of reading student narratives, and student responses. Finally, I will discuss how re-authoring - a core idea in narrative therapy—functions in this class.

\section{The Journey from Mori Akira to Narrative Pedagogy}

Mori Akira (1915-1976) is one of the leading Japanese philosophers of education in postwar Japan. He was a member of the Kyoto School of Philosophy, a group of thinkers who brought traditional Buddhist, Confucian, and Shinto ideas into transformative dialogue with western philosophy. (For an introduction to the Kyoto School, see Heisig, 2001. For an introduction of the Kyoto School in education, see Standish \& Saito, 2012; Sevilla, 2016). But Mori was also known as an expert in western philosophy—writing extensively on existential philosophy (including translating books by Karl Jaspers and Otto Bollnow) and pragmatism (John Dewey). And while most of his books were on philosophy of education, he also wrote popular books for teachers and textbooks for students. 
In a book entitled The Practicality and Inwardness of Education (1955), Mori began advancing a holistic view of education, which he termed "education as becoming human" (ningen seisei toshite no kyôiku 人間生成としての教育). While in his time, people tended to see education as heavily focused on testing and preparation to contribute to industrial life (Mori, $1977^{1}$ ) or as a "methodic socialization" to tradition, Mori saw education as balancing four tensional facets: supporting the natural growth of the child (ala JeanJacques Rousseau and Dewey), transmitting culturally valuable knowledge (ala Wilhelm Dilthey), social formation (ala Emile Durkheim), and aiding personal awakening (ala Karl Jaspers). And unlike other philosophers, he referred to developmental psychology and articulated how the balance of these facets shifts in the process of maturation, with natural growth taking the foreground in infancy and early childhood, transmission and formation becoming central in elementary school, and awakening growing in importance starting adolescence. (See Fig. 1, and see Sevilla-Liu, 2019 for a com 'plete overview of Mori's philosophy of education.)

For narrative pedagogy, it is education as awakening that is central. "Personal awakening" (jinkakuteki kakusei 人格的覚醒) is Mori's educational take on the core philosophy of the Kyoto School—self-awareness (jikaku 自覚). For Mori, no matter how healthy, intelligent, and socialized a student might be, if they are not able to come to terms with who they are and that they are, and find a sense of meaning in life, education is incomplete.

While the Kyoto School's approach to self-awareness was more mystical (something akin to enlightenment or religious conversion, as we see in Nishida Kitarô, Mori's mentor Tanabe Hajime, and Nishitani Keiji), Mori's approach to self-awareness has more affinity to narrative. This is perhaps because Mori was heavily influenced by developmental psychologists (particularly Erik Erikson and Charlotte Bühler). Mori saw the peak of self-awareness (in the sense that the Kyoto School and existentialism saw it) as developing from the organic layer of personality (direct relation with experience), the conscious layer (symbolically mediated experience), and early self-awareness (social identity and life-history-what we would now call narrative identity). In other words, Mori (1960, p. 563) grounded the Kyoto School's idea of self-awareness in a more psychological idea of identity, a "personal history" unfolding within the history of society. And he suggested that this higher self-awareness (S2) might be the locus of existential decision that forms identity (S1) without being reducible to identity - a point we will later connect to the idea of narrative "re-authoring" and the narrator self (Mori, 1977, p. 229-230). (For more on how Mori builds on the Kyoto School and the philosophical theory behind his idea of self-awareness, see Sevilla-Liu, 2021. The philosophical connections between the Kyoto School and narrative are also articulated in Sevilla, 2019.)

Adding to this view of the aims of education and the structure of human personality is the empowering focus of Mori's pedagogy. Mori advocated what he called "lifestylecentered education" (seikatsu shugi 生活主義, see Mori, 1959). In this kind of education, instead of teaching a particular definition of the human being in a "top-down" manner (what Gert Biesta would criticize as "humanism"), educators begin with the actuality of the student's own experience and way of life and facilitate the self-educative subjectivity of students. This empowering and democratic approach aligns with the very idea of "self-awareness"- a facet of education where self-education and subjectivity are front and center.

\footnotetext{
${ }^{1}$ For ease, references to Mori will refer to the year the original book was published, but the actual citations are from the Collected Works edition, Mori (2015)
} 
Fig. 1 Mori's (1955, p. 30) view of the shifting aims of education

\section{(Infancy) Personality}

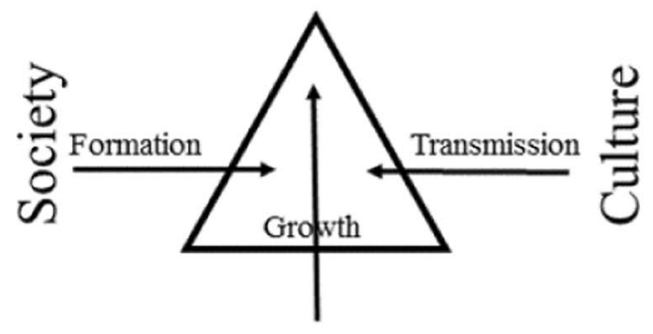

Natural Life

(Childhood)

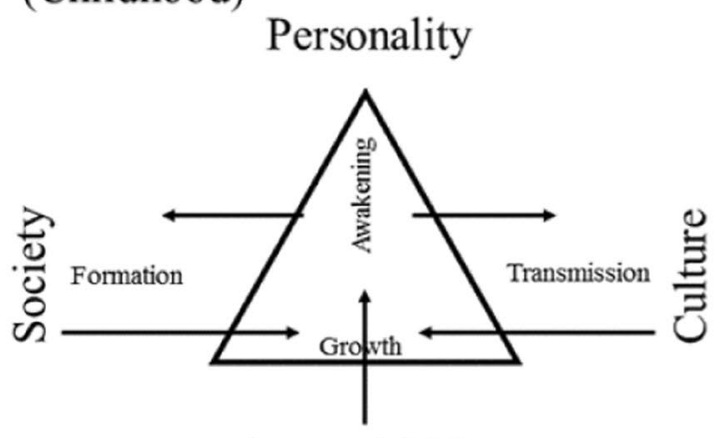

Natural Life

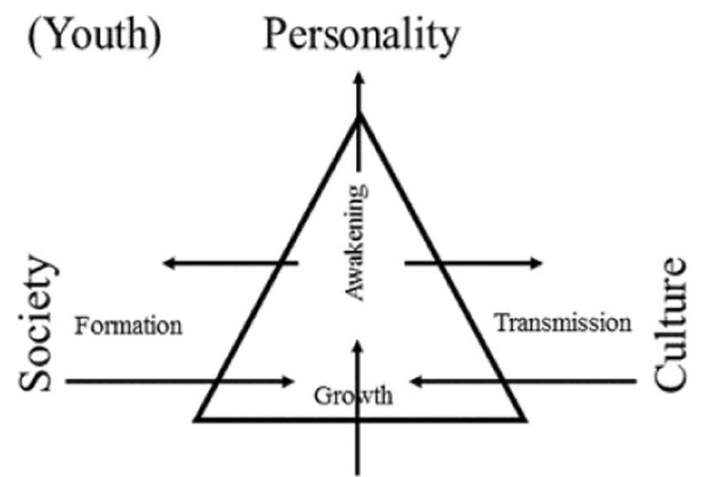

Natural Life 
However, Mori had just a few concrete hints on how to support the growing selfawareness in youth. Mori was part of a committee that wrote textbooks for moral education from elementary to middle school. The series was entitled New Life (Atarashii Seikatsu Henshû Iinkai [New Life Editing Committee], 1962), and in the volume for 3rd year middle school students, there is a lesson called "How the Self has Matured" that was most likely penned by Mori himself (judging from how neatly they overlap with Mori's books, see Mori, 1958, 1959). In this lesson, students read about the classic educational story about the "wolf-children," Amala and Kamala, and discuss what it means to become human. They then learn the basics of Erikson's stages of identity development and the various struggles (for trust, autonomy, initiative, industry...) that people go through in order to become human. At the end of this class that mixes narrative and paradigmatic learning, students work on the following autobiographical questions:

Think of the following and write your own autobiography: 1. Your ancestors, to the extent you know of, 2. The parts of your hometown's customs that are memorable,

3. People who strongly influenced your growth, 4. Events that left an impression, 5.

Books that deeply moved you. (p. 93)

Analyzing this exercise with Mori's own theory of early self-awareness (S1), one might hypothesize that assigning autobiographical activities can help students have greater awareness of their own story-understand themselves not just paradigmatically but narratively - and give that story a voice within their education, thus supporting the growth of self-awareness.

However, this single class was not sufficient for me to weave a workable "narrative pedagogy." It was my encounter with the writings of psychologist (personology, development, personality) Dan P. McAdams that became the largest influence on how I teach narratively. McAdams has spent around four decades doing research on the life story. From his work, I learned detailed processes on how to conduct autobiographical exercises, be they via interview (McAdams, 2008), written (1997b), or in a classroom setting (1988, McAdams and Guo, 2014). McAdams uses these stories to understand how people conceptualize themselves (like Mori's S1)—narrative identity. And like Mori, McAdams developed this approach from the psychology of Erik Erikson and Henry Murray. However, McAdams goes completely beyond the sphere of Mori's competence in his close analysis of the facets of narrative and ways to nomothetically code stories. Particularly helpful for me as I was beginning to foray into narrative pedagogy was learning how to code for motivational themes (McAdams, 2002), redemption and contamination sequences (1998, 1999), and imagoes (1988), allowing me to summarize the overwhelmingly rich stories of my students. In succeeding sections, I will detail how I use these codes to help students as well.

However, while coding helped me make sense of the overall direction of the stories in each class as a whole, I noticed that it was drawing me away from Mori's philosophical commitment to lifestyle-centered education. Instead of starting from the direct experiences of students, I was beginning to center myself as an "expert analyst," telling students what their stories mean. Also, some students seemed to feel pinned down by the weight of their stories as if they "defined" who they are as an answer rather than an ongoing question.

What moved me beyond this impasse was an intensive workshop on narrative therapy (2018) in Dulwich Centre, Adelaide. Here, I learned of Michael White's and David Epston's (1990) approach of "centering client knowledge," of exploring stories but externalizing them (instead of using them to define people, see White, 2005, 2007; Duvall and Béres, 2011). And most importantly, I learned of re-authoring, a process of deconstructing and re-constructing one's own narrative identity—-that pointed to a "self" beyond identity. 
I would later find out that Winslade and Monk (2006) were already trying to apply this to education (via school counseling). All these narrative therapy ideas not only brought me back to Mori's (post-structural) political focus on lifestyle-centrism but also to a concrete suggestion of how to support the growth not only of S1 but of $S 2$.

It was through this journey above-from Mori Akira to Dan McAdams and to White and Epston - that I was finally able to design my narrative university orientation class.

\section{Designing a University Orientation Class (Narrative Version)}

At Kyushu University, one of the oldest national universities in Japan, 1st year students are required to take an 8-week course called "KIKAN [Core-Curriculum] Education Seminar." This seminar functions as an introduction to university life and as a form of (pre-)career education, meeting once a week for $90 \mathrm{~min} .^{2}$ The official class objectives are as follows:

The KIKAN Education Seminar is an introduction to learning in a university setting. "What does it mean to study at a university?" "What should I learn here?" "How should I approach learning?" In this course, students think and reflect about fundamental questions like these, share and discuss their thoughts with other students through various group activities, and learn how to express their realizations in a communicative way. One of the highlights of this course is a presentation each student gives in front of around 17 fellow students, on his or her views about learning. By both giving and listening to these presentations, as well as through the other activities in this course, students increase their understanding, self-awareness, sense of involvement, and motivation for university learning, thus building a foundation for learning that is adaptive, continuous, critical, and creative. (For details on this class, see Center for the Future Development of Education, 2020.)

Japan (like other East Asian countries) has a very rigorous (and stressful) university entrance examination system. Doing well in these exams and gaining admission to a prestigious, top-ranked university is often spoken of by students as the "key achievement of education." As a result, by the time they enter our university, many of our students have already "gotten it over with" and seem to have little motivation to actively learn in university classes. Furthermore, they are used to a steady diet of rote learning, and the freedom of university education can be bewildering for many. This class was designed with this background in mind. (For more on credentialism in Japanese education, see Dore, 1976. In the next sub-section, I will share my own background, for those interested in seeing the etic lens from which I approach Japan.)

During the COVID-19 pandemic, the class took a slightly modified (and online) form with the following flow:

Day 1: Introduction and Teacher's Learning

Day 2: Thinking about One's Learning, Past and Future

Day 3: Making One's Final Presentation (Theme: "What I'll Learn in UniversityMy Reasons and Their Significance.”)

\footnotetext{
${ }^{2}$ In interest of full disclosure, let it be noted that the author is a member of the committee that designs this class
} 
Day 4: Watching and Responding to Presentations

Day 5: Writing Your Essay Draft

Day 6: Peer Review of Essays

Day 7: Submission of Final Essay

I had taught this class for 5 years (1 or 2 classes a year, each with 17-20 students, from 18 to 20 years-old). However, there were certain points I was personally uncomfortable with. Given my philosophical background in Mori's "education as human becoming," I was concerned that learning and career were being reduced to mere knowledge and skills. (For example, day 2 usually considered various OECD defined learning skills and employee interview questions.) Also, while this class strove for "active learning" (What do you want to learn?), the subject behind this active learning seemed to be a capitalist view of the self (homo economicus and its desires) or a social self burdened by expectations of a "successful life." I found it to be too narrow a view of the student and education, clashing with the purported aims of "increased self-awareness." And so drawing from Mori Akira, McAdams, and narrative therapy, I made a "narrative version" of the KIKAN Education Seminar in 2018 (in cooperation with a colleague, Bartosz Wolanski, since 2019). I present the latest version taught in 2020.

This narrative version has four main features. First, learning is connected primarily to each student's experiences and life story (rather than competencies and successes determined "top-down"). Second, the teacher models this narrative approach by sharing their own life story and how it connects to learning. Third, to explore their own stories, after each day, students do a 15-min written autobiographical exercise. And fourth, students make a final presentation and essay about "My Story and My Learning"- showing not just what they want to learn but the narratives that drive their interests.

While the initial inspiration came from Mori's autobiographical exercises in "How the Self has Matured," I updated it using McAdams' life story interview. McAdams' interview focuses on what Mori calls "events that left an impression"-but his way of asking it inevitably connects with significant others, one's cultural context, and other influences (which Mori asked more directly). Interestingly, like Mori, McAdams (1988, p. 282-288) first formulated his life story interview as a series of questions asked to students over the course of (university) classes held from 1981 to 1982!

Simplifying McAdams' (1997b) life story interview, I formulated the following five autobiographical exercises:

Day 1: Please begin by thinking about your life as if it were a book or novel. Imagine that the book has a table of contents containing the titles of the main chapters in the story. What would that table of contents contain? Try to divide the book into around 2-7 chapters. Please give each chapter a title. Write a sentence or two about what happens in each chapter.

Day 2: High point. Please describe a scene, episode, or moment in your life that stands out as an especially positive experience. This might be the high point scene of your entire life or else an especially happy, joyous, exciting, or wonderful moment in the story. Please describe this high point scene in detail.

[The following paragraph's instructions are repeated in days 3-5.] What happened, when and where, and who was involved? (4-6 sentences) If you haven't written it yet, what were you thinking and feeling then? (2-4 sentences) Why do you think this particular moment was so good [or in the next days, bad/a big 
change/consistent]? What does the scene say about who you are as a person? (1-3 sentences)

Day 3: Low point. The second scene is the opposite of the first. Thinking back over your entire life, please identify a scene that stands out as a low point, if not the low point in your life story. This can be a bit difficult to write about, so you don't have to choose the worst time of your life. Pick an event that's bad but you can still write about. What happened in the event, where and when, and who was involved? (4-6 sentences)

Day 4: Turning point. In looking back over your life, it may be possible to identify certain key moments that stand out as turning points - episodes that marked an important change in you or your life story. It can be a positive or negative story. Please identify a particular episode in your life story that you now see as a turning point in your life. Or describe some event in your life wherein you went through an important change of some kind. (Choose a story different from the ones in the high point and low point.) Again, for this event please describe what happened, where and when, and who was involved. (4-6 sentences)

Day 5: Continuity. Now we would like you to focus on an opposite kind of experience from last week. Rather than focus on an experience of change, we want you to consider a moment in your life story in which in some way you demonstrated a sameness or continuity in your life. Think back on your life in the recent past (e.g., the last two years or so) and choose a single event or experience that you believe illustrates something within you that is stable and unchanging. This event should reveal a pattern in your life that occurs again and again. Again, for this event please describe what happened, where and when, and who was involved. (4-6 sentences)

The four stories (high point, low point, turning point, and continuity point) are "nuclear episodes"- key stories that stand out in the life story as a whole, highlighting key concerns in narrative identity (McAdams, 1988, pp. 134-140). Adapting analysis to the classroom, the week after each exercise, I taught students the core principles of "coding" for motivational themes, redemption/contamination sequences, imagoes, etc., as a means to reflect deeper into their own life stories.

A brief word on research ethics Students were all informed that the general observations of the class would be part of a narrative research project. But only those who voluntarily submitted consent forms at the end of the semester would have their individual data analyzed and used in research. However, this paper focuses only on the general observations of the class.

\section{Teaching Narratively}

What is the experience of teaching narratively? How does it change the class when one teaches not merely skills and life plans but connects these to significant life events that the students themselves go through? What is it like to read these autobiographic exercises with students? In this section, I share my personal observations of the class in order to find hints on how narrative transforms the teacher, the classroom, and perhaps the students as well. 


\section{Day 1: Introduction and Teacher's Learning}

After some paradigmatic introductions, this narrative class properly begins with a story-my life story and how it connects to my learning. I told students that this presentation would be quite similar to the daily exercises they would be doing and the final presentation they would make-that they could use it as a model of sorts. I share it in this paper to give a background of my outsider perspective as an "ethnographer" to Japan.

For my life story presentation entitled "The Ups and Downs of My Philosophy Life," I began with my table of contents where I divided my life into 4 chapters:

1. The Philippines?

2. Wild Kid in a Rich Boy's School

3. The New Teacher "Grandpa"

4. My Training in Japan

5. Becoming a Sensei again.

In the first chapter, I talked about my country of origin. Although I am a naturalized Japanese now, I was born in the Philippines. In the second chapter, I spoke of my education at an elite Jesuit university (with Spanish and American influences that make the education quite heavily "westernized"). I shared the great difference between Japan's rote learning and entrance exam focus with my school's holistic and continuous learning focus. I talked about my continuing confusion back then as to what to major in (and how I shifted from major to major, something Japanese universities make very difficult). But more positively, I shared my encounter with philosophy and how I learned that building a deep connection between my own experiences and my academic pursuits could put me in touch with a deep source of insight and creativity.

In the third chapter, I shared the "high point" of my life, my early days of teaching where students called me "lolo" (Filipino for "grandfather"), reflecting the warm and close relationship I had with them. I also shared my "turning point"-a major conflict with my friends that led me to question my own values and the philosophy I had used to explore that.

For my fourth chapter, and as part of my response to this conflict, I moved to Japan to study a philosophy that would augment my narrow view of life and ethics. But as I shared with them, this would also be my "low point"- of loss of direction and a growing sense of isolation from others. I suggested the idea of conflicting kinds of "self" in a story (here between my "Grandpa" self and my "success-seeking self"). And in the final chapter, I talked about becoming a teacher (sensei) again, and shifting to philosophy of education in an attempt to be true to myself but within the new parameters of my situation in Japan.

Having heard my presentation, the first autobiographic activity of the students was writing the "Table of Contents" of their life stories. In their submissions, many students subdivided chapters by quite obvious categories-what level they were at school, or where they lived. But the content of each chapter was rarely about school per se. Often it was about school club activities (baseball club, etc.), or how their relationships were with friends and family. As an education-centered nation, school is so dominant in the lives of Japanese students (see Dore, 1976). But these results were a reminder for me, as a teacher, to remember that school is hardly the center of students' lives. While superficially, school dominates students' lives, there is so much more going on under the surface with how they give meaning to it existentially. 
The week after, I taught them McAdams' approach to analyzing the table of contents. I would repeatedly tell them, "Because of social pressures, sometimes it's difficult to be honest about who we are. So, what we're trying to do here is to approach ourselves circumspectly [kansetsuteki ni 間接的に] to see if we can discover something new.” I suggested they notice how they were dividing chapters and the kind of content highlighted in the chapters, and ask themselves, "What is this telling you about what matters to you?".

\section{Day 2: Thinking About One's Learning, Past and Future}

On day 2, students wrote about their high points. In trying to get a feel of my classes (2 classes of 20 students each this year), I needed to rely on something to help me simplify the data. In the past few years, I would read the stories and be left completely bewildered by the sheer plurality of what I had read. For this reason, I began using McAdams' (2002; McAdams et al, 1996) coding for motivational themes (which draws heavily from the Thematic Apperception Test) just to get my bearings on the kinds of concerns that arise. However, to balance McAdams with Mori and White and Epston, I did not use these nomothetically (privileging scientific generalizations) but just as a heuristic from which I would return idiographically to the particularities of each story. ${ }^{3}$ A summary of the coding is in the following table:

\begin{tabular}{ll}
\hline Agentic themes & Communal themes \\
\hline Self-mastery (SM) & Love and friendship (LF) \\
Status \& victory (SV) & Dialogue (DG) \\
Achievement and responsibility (AR) & Care and helping (CH) \\
Empowerment (EM) & Unity and togetherness (UT) \\
\hline
\end{tabular}

Through these codes, I noticed that most of my students talked about "success"-passing the Kyushu University exam, sports achievements, etc. (often SV and AR). I wondered what this focus on "success" was telling me about the social expectations on students and how this was influencing their self-presentation. Additionally, stories of a sense of closeness to a group and friendships (UT and LF) were quite common. A few students spoke about self-discovery (SM) as high points as well.

When I shared my observations with the class in the following week, one of the things I pointed out to the students is that the same story ("passing university exams") could be showing very different motivational themes. It could be about success (SV), but for others, it could be about receiving support from their parents (EM) or a sense of camaraderie in studying with their friends (UT). I taught the students the idea of "motivational themes" (without going into the detail of the code-although I had tried that in 2019 with little success) and suggested they really try to see what was really driving them in that story (rather then what society says should be driving them) — in an attempt to shift the "coding" from expert-centered to student-centered. This is a key point that connects to both Mori's lifestyle centrism and White and Epston's post-structuralism.

\footnotetext{
3 This is a pedagogic application of a research method our team is developing called "NomotheticIdiographic Narrative Analysis." However, I leave the details of this method to further research
} 


\section{Day 3: Making One's Final Presentation}

On day 3, while preparing their final presentation, students wrote about their low points. What struck me was that most students talked about some interpersonal problem with friends or family or their class. There were discussions of failure in exams or competitions, but not quite as many, and often even these highlighted a sense of social disappointment. For me, this demonstrated clearly Mori's suggested overlap between the socio-cultural side of development (stressed in education as formation and transmission) and the personal side (self-awareness). (See Fig. 1.) One cannot separate self-awareness from their culture of socially imposed demands.

I shared these findings with the class and taught them the idea of "negative motivational themes" (a modification of what McAdams does in 1988, pp. 158-159) using my own story of my difficulties as an immigrant. Negative motivational themes show us what we value via the negative affect resulting from their being confounded. This is similar to what narrative therapists explore with their clients in "statement of position maps," where clients map out where they want to stand vis-à-vis a problem, thus clarifying what they value even in negative situations where values seem difficult to see.

\section{Day 4: Watching and Responding to Presentations}

On the fourth day, students shared their preliminary reflections on what they wanted to do in university and why. Students would usually talk about their dreams (becoming a doctor or researcher or artist...) and what they would have to study for that. And behind these dreams, they would talk about positive experiences that inspired them on this path or negative experiences that showed them what they value, thus "negatively" inspiring them, etc. I felt that there was quite a range in how connected their plans were to their life stories. For some students, their plans connected clearly to their life stories, and for others, there was no seeming connection. And sometimes, their life stories seemed to suggest motivations that would be at odds with their chosen career!

Students commented on each other's presentations. It was heartwarming to see them bond over shared hobbies they discovered in presentations. (This was amidst the loneliness of quarantine and forced online learning.) And sometimes, I could see them wrestling with their own issues when they asked about how a particular decision felt or why they chose it. Many students mentioned how they never had the opportunity to talk to people about these things - and how interesting it was to have people's lives and dreams so honestly displayed. (I myself was surprised at the level of self-disclosure. Students are encouraged to say no more than they are comfortable to, but they were far less shy than I expected.)

At the end of the class, they wrote about their turning points. I was quite relieved to find that most of their stories had to do with redemptive sequences (when a bad situation is redeemed and becomes good) rather than contamination sequences (when a good situation is spoiled by a negative turn). (See McAdams, 1998, 1999.) And these stories tended to talk about friendship, being mentored, and changes in school environment-changes that sometimes involved moments of intense self-discovery.

However, their contamination sequences were very often about competence-stories of their view of life taking a dark turn when they realized they were not successful enough or good enough in the eyes of others. This suggests that their identities are greatly troubled by the specter of "measuring up." This realization was deeply disturbing for me, because I realized that I myself tend to motivate my students via appealing to competitiveness and 
the need for relative competence. And so this journey of my students shapes me as well, as I think of ways to motivate students that do not needlessly trigger their narrative issues.

In class, I shared with students some empirical research about redemption and contamination sequences as markers for mental health. I think there was a temptation to get very nomothetic and abstract here. But rather than teach these as mere facts, again I tried to reframe them as "heuristics" - an opportunity to ask themselves, "How am I feeling about my life as a whole?" "Are there things that are suggesting to me that I might need some extra self-care (or to seek help)?".

\section{Day 5: Writing Your Essay Draft}

The fifth and final story was about continuity points, and most students shared stories about having or lacking diligence/self-control, etc. It made me wonder how heavily they must be carrying the experience of having just gone through a rigid regime of social sorting ("examination hell"). Other students talked about their struggles with indecisiveness, the difficulty of dealing with novel situations, conflict with leadership, etc. McAdams does not often inquire about continuity points, but I noticed that while the other nuclear episodes tended to be "zoomed-out" (like an autobiography), making it very difficult to see what the student was presently wrestling with, the continuity point draws closer to what narrative therapy covers - with certain stories showing dominance (a central plotline relative to others), other stories showing the pursuit of alternatives (attempts to move away from the dominant plotline), and with all these a clearer sense of struggle and directionality.

I taught the students about McAdams' (1988, p. 178) idea of imagoes, “... idealized and personified images of self which function as characters in the life stories which are our identities." I used my own story that I had shared of this "success-seeker" (constantly sacrificing a sense of communion with others in order to be superior) that dominated my learning from the undergraduate level all the way to graduate school. I also showed that they could have multiple personas (in my case, along with the "success-seeker," there was the "Grandpa" - the part of me that tries to connect with people in a loving, grandfatherly way). This was an opportunity for them to examine the kind of personas that were coming out in their four stories.

\section{Weaving the Strands of Narrative Pedagogy I}

Days 1 to 5 aim to help students become more aware of their own narrative identity. By looking at the key events in their lives, they are able to approach themselves narratively (instead of via the much more overt paradigmatic process of "pitching themselves" which students do for university and job interviews) and hopefully get a more intimate view of how they are pulling together the various experiences of their lives. Using a heavily simplified version of McAdams' approach to narrative psychology, they examined nuclear episodes, motivational themes, narrative sequences, and imagoes that emerge. This hopefully made students more aware of the social identity (Mori's S1) behind their career and learning choices-bringing career education and university orientation closer to Mori's education for self-awareness.

However, there are certain key design principles that have been illustrated above, which illustrate the combination of Mori, McAdams, and White and Epston. As I have mentioned, while Mori's lifestyle-centered education encourages teachers to know their students better, students need to know themselves better too. This was strengthened by the narrative 
therapy idea of "centering client/student knowledge." Because of this, McAdams' codes (motivational themes, sequences, imagoes) were taught to the students as a tool for selfanalysis. Also, rather than nomothetic analysis, these codes were used heuristically for an idiographic, phenomenological approach (the principles of which can be found in Smith, Flowers, and Larkin, 2009).

Second (and a point many students noticed), the majority of this class was spent learning about themselves and their classmates via stories, rather than about theory. What this accomplishes is a shift from "dominant/unitary knowledge" (of experts and adults ${ }^{4}$ and adult institutions like the OECD) to "subjugated knowledges" that are more indigenousfellow students grappling with similar decisions and problems (White \& Epston, 1990, pp. 30-31).

Third, and combining the first two points, what this hopes to achieve is a shift not only in individual students, but also in the whole discourse of education. As can be seen in my observations above, reading these stories really made me rethink how to teach. I had always been somewhat annoyed with students who took grades too seriously — but here I began to see for the first time what lurks in/behind their concern for grades. It made me re-think the kind of pressure I put on them to perform in school or to behave properly (something I had previously done as a matter of habit, replicating how I had been taught without responding to my students in their particularity). It challenged me; it challenged other teachers of this class; it challenges potentially the whole Kyushu University to ask, "Does our education respond to students as entire persons, with the complexity of the narratives they hold? Or are we responding to just a narrow fragment we project upon them as their role? Do students really matter to us?" This is what Winslade and Monk (2006) refer to as changing the discourses in schools - but this time not via counseling but via narrative practice in classrooms.

\section{Re-authoring in Narrative Education}

For Mori, social identity (S1) developmentally leads up to a higher stage of self-awareness (S2) - the jikaku which the Kyoto School and existentialism depict. But while he conceptually explained S2 in 1955, he did not discuss its details until his last book, The Fundamental Principles of Human Formation (1977), which he wrote while he was dying. (For the philosophical development of Mori's idea of self-awareness, see Sevilla-Liu, 2021.)

In this book, Mori (1977, pp. 230) draws from the educational anthropology of Heinrich Döpp-Vorwald and suggests that while S1 is a "life history" or narrative identity, behind it lies an Existenz, taking a stance toward reality, deciding, taking responsibility, projecting itself (in the Heideggerian sense of Entwurf). In other words, he sees S2 as the narrator of the narrative, and thus, as always more than and irreducible to the stories it tells. Interestingly, right after discussing this, he discusses career education-almost as if to suggest that career can be founded not merely on inclination, social demands, or identity but on this narrator (pp. 241-246) — but the book abruptly ends here, with Mori's passing.

In order to realize this idea that Mori may have been on the verge of clarifying, I attempt a process of reconstruction that may suggest how we might support the student's own self-education

\footnotetext{
4 Small cultural note: My students (18-20 years old) generally do not consider themselves "adults" (otona 大人). From my conversations with them, it appears society does not recognize them as adults either until they have jobs and become "full-fledged members of society" (shakaijin 社会人)
} 
of S2. (Strictly speaking, one does not and cannot "teach" S2!) In the textbook for 2nd year middle school students he co-wrote, there is a lesson called "The Feeling of Searching for Myself."

...we find a story about the homeroom class of a boy called Genji. The teacher raises an example from another student, Kiyoshi's diary. Kiyoshi overheard his parents talking about him, but when he asked them about it, they responded, "This isn't something children should be listening to (or asking about)." Another day, after forgetting to clean up as he promised, his mother scolded him. "Kiyoshi, you're not a kid anymore, you know." This riled him up- "They always say 'you're just a kid', but times like this they say 'you're not a kid anymore'. Adults are so full of it." The textbook then details the homeroom discussion that follows, where Genji's teacher talks about the physical and psychological changes in adolescence. Diary writing, rebellion, the sense of being misunderstood-all of these are raised affirmatively, as examples of the birth of a new self. (See Sevilla-Liu, 2019)

The lesson ends by asking students to "Write an essay about something that happened this year when you underwent a big change, psychologically, and what you think about it. Put together an essay collection with your class" (Atarashii., 1962 [2nd Year], p. 105).

This lesson draws the attention of students to multiple roles (and imagoes) that they havekid, son/daughter, student, and young adult. Students are often taught about the expectations and ideals of one role - and this role is used to pull together various aspects of their personality as an identity (e.g., "Kiyoshi the kid"). But by drawing attention to multiple roles and how they conflict ("I am a kid, but I am also not a kid anymore."), the student is given an opportunity to take a stance outside the identity to reflect on it. S2 is none other than this I that is looking at its identity "as a kid" and "as no longer a kid," irreducible to either.

This can also be done by journaling. "One writes one's thoughts, worries, reflections, dissatisfaction and criticisms toward adults in a journal, trying to look at oneself by oneself [jibun de jibun o mitsumeyô 自分で自分を見つめよう” (ibid.). One way to read this is as a simple suggestion to reflect independently. But more in line with Mori's theory is to see this as encouraging students not to just do (from the standpoint of narrated self) but to think about this doer (from the standpoint of the narrator). Both highlighting conflict and using reflection are ways to encourage a growing awareness of $\mathrm{S} 2$ beyond $\mathrm{S} 1$.

In order to have more concrete suggestions for S2, I turned to narrative therapy. While narrative therapy focuses on our lives as storied, it does not reduce people to their stories but highlights the act of storying and re-storying. However, it is not possible to negotiate one's story if one sees oneself as reducible to a story. (For example, Kiyoshi cannot struggle against being "a kid" if he cannot see the parts of himself that are "not a kid anymore.") White and Epston (1990, p. 11) cite E. Bruner: “... life experience is richer than discourse. Narrative structures organize and give meaning to experience, but there are always feelings and lived experience not funny encompassed by the dominant story." It is by taking the stance of lived experience irreducible to one story - the stance of the narrator (S2) - that one is able to redraw the lines of one's story. They call this "re-authoring"- a process of building and emplotting previously overlooked "unique outcomes" into an alternative story (p. 16).

However, narrative therapy is generally used for people who are wrestling with a problem-they are "clients." The usual approach is to ask clients to tell the story of their problems and then help them find their way to alternative stories. I had tried to do this in earlier versions of the narrative class, but many students found this very intrusive. I slowly realized that my approach may have been culturally inappropriate. However, the connection between Mori's instructions, turning points, and re-authoring suggested to me that it might be possible to integrate narrative therapy and S2 in a less intrusive way. 


\section{Designing the Reflection Process}

After asking each student about their table of contents, high point, low point, turning point, and continuity point, students had a general view of their identities. But starting day 6 (where people were more accustomed to talking about stories and rapport was better), we shifted angles:

Day 6: Reflection. Review your table of contents and four stories. Write out your table of contents (the chapters and titles) and which stories go where. Then, think about the kind of person you personally want to become, and the kind of challenges you are facing on that path. Which of these four stories is the most helpful for you to remember? Perhaps it motivates you, or reminds you of something important. (It can be a positive or negative story.) If it's okay, please share in what way it helps you. Lastly, are any of these four stories unhelpful or harmful for you as you try to become what you want to become? Perhaps the story makes you less motivated, distracts you, or reminds you of something you want to let go of? (It can be a positive or negative story.) If it's okay, please share why it is not helpful.

Day 7: Looking Back. How was the experience of looking back on your life story? Are there any activities you found particularly helpful or inspiring or pleasant? Are there any activities you found difficult, unpleasant, or unhelpful? (2-3 sentences) Did you discover new things through this class? What kind of things? Were these completely new discoveries, or things you already knew that became clearer? (2-3 sentences) Do you think you will continue this sort of reflection after this class? If so, in what way? (1-2 sentences)

My use of the binary "helpful vs. unhelpful" highlights conflict within identities/aspects of identity and encourages students to take a stance external to their stories. This is similar to Mori's highlighting of conflict between Kiyoshi's roles and his description of the value of journaling but combines with narrative therapy's approaches to problem/preferred stories and reauthoring.

First, McAdams' questions on nuclear episodes show a somewhat de-contextualized view of a life. The stories alone do not show the direction the narrator wants to take their life towards or what struggles they are facing along the way. By asking which stories are helpful and which are unhelpful, this exercise encouraged students to see how they employ the vignettes we had from days 1 to 5-similar to how narrative therapy would separate problem story from preferred story. For some, the high point and turning point would start to line up with the goals in their presentation as a preferred story, and some issues scattered in various stories (perhaps more common in low points) would connect to challenges shared in their presentation as part of a problem story.

Second, instead of thinking from the perspective of narrated self ("Who am I?"), reflection encourages their "externalization" (a process that had begun by labelling imagoes, much like naming stories) and examining one's position (as in the "statement of position map") toward these stories. Thus, one is taking the stance not of the narrated self but of the narrator, the author that is irreducible to any story. ${ }^{5}$

\footnotetext{
5 However, one of the referees offered insightful criticisms of my approach - the very binary (helpful vs. unhelpful) I use may function as an artificial constraint, forcing students to "conform" to my requests by separating their stories in these binary terms, whether or not this suits their subjective engagement with their stories. I am still in the process of exploring how this constraint might be overcome within the limitations of the format of prepared written exercises
} 
However, as I mentioned previously, this approach modifies narrative therapy maps in several ways. First, it does not ask students directly, "What problem are you dealing with right now?" Instead, it allows problems to naturally come out over the course of talking (in a rather detached way) about one's life as a whole. Second, it does not presume that the problem story is the "dominant story" and that this is in some opposition to an "alternative story." Unlike clients in therapy (White and Epston) or school counseling (Winslade and Monk), students in class can have dominant stories that fundamentally work for them. Hence, their preferred story may actually be dominant, rather than "alternative." Hence, I split it by "preferred" and "problem" stories instead, without delving into their level of dominance.

\section{Reflecting on Our Narratives}

\section{Day 6: Peer Review of Essays}

Let us return to the story of our class. On day 6, they shared their essays with each other (with explicit instructions that they could omit parts they found too private from this draft). They also reflected on their stories (as described in the previous section).

Reading the reflections of the students, I found that around half the class did not list any story as unhelpful. Even their low points were something that they learned from and found valuable for who they are. Thus, their problem stories tended to form from various challenges and difficulties scattered throughout the four stories. In our class, many students expressed how they wanted to be less passive and be more motivated and autonomous and the various challenges in this transition.

However, the other half of the class listed entire nuclear episodes as unhelpful. Sometimes even their high points showed a self that they wanted to distance themselves from, that they want to get over but have difficulty doing so. For these students, problems like passivity or just doing what other people say seemed to be more than just a challenge in life, but something that was embedded in their defining stories, perhaps something they even identified with. (I hope to explore these intuitions with them via follow-up interviews.)

In the class discussion on their reflections, I pointed out my personal concern that many of them seem to have unhelpful stories embedded into their narrative identities and suggested they think about what that might be telling them. We also returned to their goals and plans (which they shared in their presentations) and using my own example, I encouraged them to think: "If you have imagoes that are in tension with each other, like my 'success-seeker' and my 'Grandpa', which imago is driving the plans you made? Which imago is being strengthened by those plans? Are you okay with that?" I also encouraged them to rethink the idea of "active learning"- that the subject behind it was not just a self with desires or competencies, but a self with stories, and further, is also irreducible to those stories and capable of taking an active stance toward these stories. 


\section{Day 7: Submission of Final Essay}

Day 7 was the final day, and they submitted their final essay - this time with all the parts they were willing to tell the teacher privately added in. The students also reflected on their experience of the whole class, giving some indication of how the class was for students.

As the teacher and designer of this class, I was very encouraged by how most of the students found this class to be unlike any other class they had experienced, and how it had helped most of them clarify things they already knew, but only vaguely, about themselves. Most spoke about how introspecting on their stories shaped them, but a good number mentioned how moving it was to read the stories of others and see how many seeming "achievers" are just as lost as they. This showed me that this class might be having an effect (perhaps a small one) not only on the students as individuals, but also on the whole social discourse in education of "success" and "achievement."

Most of the students expressed an interest in continuing this sort of reflection, and a few gave concrete ways they hoped to do that (journaling, reflection periods in times of major life changes, etc.). Several students also shared that they were re-thinking their dreams and goals, having realized that there was a lack of alignment between their goals, their stories, and the direction they were wanting to take their stories.

I realize that seven days of narrative thinking and self-education can do little to transform an entire institution and society whose definition of education is far narrower than Mori's "education as human becoming"-and the overall effects of such a system on individual students. But this feedback showed me that perhaps this kind of education is a start, that it provides some options, for students to better weave their lives into the future.

\section{Weaving the Strands of Narrative Pedagogy II}

The first five days of the class provide an exploration of the narrated self (S1) combining Mori, McAdams, and White and Epston. The last two days bridge this growing awareness toward existential self-awareness of the narrator behind this story (S2), again combining narrative philosophy, analysis, and therapy. I think truly developing S2 requires 1-on-1 work-perhaps narrative counseling. But I believe this class might open that door for students to realize that there is work to be done in that area-and that we, their educators, care about that narrative work too.

I think the last two days also give potential insights for how to combine these three strands of the narrative approach. First, Winslade and Monk tend to focus on "problematic students” (mondaiji 問題児, although Winslade and Monk would never label them that way, like society does!) — those struggling with truancy, bullying, drug-addiction, stealing, ADHD, etc. And indeed, students like this need narrative assistance. However, what Mori's philosophy and my action research suggest is that maybe we need to expand the range of narrative practice. All students need to grow in self-awareness. And even before students get called into the counselor's office for some trouble they fell into, even before students teeter around the edge of these troubles and struggle with them, and even while students may be doing great in school and with friends and family, they may be struggling with narrative problems.

Many of my students are the opposite of the "problem-child," but are what we call in Japanese “ii ko いい子” (good kids) or “yûtôsei 優等生” (achievers). However, one pattern that came up regularly in the reflection is how very well-adjusted students are weary of just 
following what parents, teachers, and other authorities tell them to do and to value. (This is very similar to the Korean context presented by Lee, 2017.) "Achievers" are not sent to the counseling office_-but "achiever" can be a dominant problem story, bolstered by a whole society of conformity, that students need to re-author. Narrative pedagogy expands therapy to tell the stories of all, including those marginalized by their own success.

Second, narrative pedagogy demands a rethinking of the very idea of educative relationships. Mori writes of education as "journeying together" (Sevilla-Liu, 2021) — a relationship not of master and disciple but of teacher and student who are "equal before the absolute [truth]." This also has resonances with how narrative therapy tries to deconstruct (White, 2005) the authority of the therapist over the client (also seen in my use of nomothetic codes as "heuristics").

Seen concretely in my action research, perhaps the teacher's self-disclosure plays quite an integral role for students to open up. It models the narrative attitude and it uses the authority of the teacher to subvert the tendency to ignore the narrative in favor of the paradigmatic in academic settings (at least in Japan). But also, I think the learning here is something two-way, and my wrestling between "success-seeker" and "Grandpa" (especially manifesting in how I teach) is shaped by seeing how my students struggle with success and self-determination.

Third, narrative pedagogy reconsiders the relationship between students. In the stories of students, we see that behind their motivations and struggles, there is a view of the world of students as one of competition, a zero-sum game where people are sorted into winners and losers based on who can better understand the paradigmatic, universal knowledge being conveyed in school. However, compared with my previous experiences with the non-narrative version of the university orientation class, the practice of narrative pedagogy seems to nudge the relation of students away from competition in a world of paradigmatic knowledge to a world of narrative where each has their own story and is presented with the possibility of learning from and journeying with others. In narrative therapy, this would be called restoring "indigenous knowledge" of students - in resistance to the dominant discourse. And this is no longer individual therapy but narrative as a "social movement" (Denborough, 2008) that attempts to transform society itself.

\section{Conclusion}

In this paper, I have shared my journey into narrative pedagogy from Mori Akira to Dan McAdams and to White and Epston's narrative therapy. Through my action research on a university orientation class, I have shown how it might be possible to support the growing selfawareness of students in class. Autobiographic exercises examining students' nuclear episodes (high point, low point, turning point, continuity) may help students become aware of their own narrative identity, and McAdams' nomothetic coding can be re-tooled to aid in self-analysis. Through reflection exercises inspired by narrative therapy, this growing awareness of "narrated self" can shift toward the "narrator self"- the subject of re-authoring - in a way that empowers a student not only to be aware of their life story but also to actively shape it.

This action research concretely showed how the three strands of the narrative approachphilosophy of education, analysis, and therapy — can be woven together as narrative pedagogy. In the process of this weaving, I suggested key design principles (or perhaps "challenges") for narrative pedagogy: to approach narrative in a way that helps students in their self-education by centering the subjugated knowledges of students, to broaden narrative 
approaches to include not only "problematic" students but all learners, to rethink the pedagogic relationship between teachers and students and between the students themselves, and finally, to start to shift the discourse of education toward a deeper concern with identity.

But perhaps the astute reader has also noticed that there are resistances to integration. (For example, the nomothetic approach of McAdams can clash with the need for a pedagogic approach and student empowerment. Narrative therapy's focus on clients can clash with the need for a more universal approach, etc.) I hope that other researchers might continue to elucidate both the connections and the differences that make this tapestry of narrative approaches complex and interesting.

Funding This paper was written with the aid of funding from Japan Society for the Promotion of Science (JSPS) Grants-in-Aid for Scientific Research (Project Number: 17K13988).

\section{Declarations}

Ethics Approval The activities of this project have already been reviewed by the Kyushu University Faculty of Arts and Science Research Ethics Committee. It has been passed under project number 201901 (ナラティヴ 授業 実践の質的研究——学生の学習物語——, “Qualitative Analysis on Narrative Class Praxis: Student Narratives of Learning").

Consent for Publication As these are based on action research of the author's own experience, participant consent (other than institutional approval by Kyushu University) is not required.

Conflict of Interest The author declares that there is no conflict of interest.

\section{References}

Atarashii Seikatsu Henshû Iinkai. (1962). Atarashii seikatsu 1st to 3rd Year [Middle School]. Tokyo: Tokyo Shoseki.

Center for the Future Development of Education, Kyushu University. (2020). Akutibu rânâ o hagukumu: Shin jidai o kudaku kikan kyôiku. Kyûshû Daigaku Shuppankai.

Clandinin, D. J., \& Connelly, F. M. (2004). Narrative inquiry: Experience and story in qualitative research. Jossey-Bass.

Denborough, D. (2008). Collective narrative practice: responding to individuals, groups, and communities who have experienced trauma. Dulwich Centre Publications.

Dore, R. (1976). The diploma disease: education, qualification and development. University of California Press.

Duvall, J., \& Béres, L. (2011). Innovations in narrative therapy: Connecting practice, training, and research. W. W. Norton \& Company.

Goodson, I., \& Gill, S. (2010). Narrative pedagogy: Life history and learning. Peter Lang.

Goodson, I., \& Gill, S. (2014). Critical narrative as pedagogy. Bloomsbury Academic.

Heisig, J. (2001). Philosophers of nothingness: An essay on the Kyoto School. University of Hawaii Press.

Kojima, H., \& Sugita, H. (2014). Dôtokuteki kachikan no saikôchiku ni okeru naratibu no yakuwari ni kansuru ichi kôsatsu. Kyôikugaku kenkyû kiyô, 60(1), 13-24.

Langdridge, D. (2007). Phenomenological psychology: Theory, research and method. Pearson Education Canada.

Lee, Eunjoo. (2017). Conformity pressures: Deconstructing social discourses in the Korean context. International Journal of Narrative Therapy and Community Work, 1.

McAdams, D. ( 1997a). The stories we live by: Personal myths and the making of the self. The Guilford Press.

McAdams, D. (1997b). Guided autobiography. Retrieved from https://www.sesp.northwestern.edu/foley/ instruments/guided/

McAdams, D. (1988). Power, intimacy, and the life story: Personological inquiries into identity. The Guilford Press. 
McAdams, D. (1998). Coding systems for contamination sequences. Retrieved from https://www.sesp. northwestern.edu/foley/instruments/contamination/

McAdams, D. (1999). Coding systems for redemption sequences. Retrieved from https://www.sesp. northwestern.edu/foley/instruments/redemption/

McAdams, D. (2002). Coding systems for themes of agency and communion. Retrieved from https://www.sesp. northwestern.edu/foley/instruments/agency/

McAdams, D. (2008). The life story interview. Retrieved from https://www.sesp.northwestern.edu/foley/ instruments/interview/

McAdams, D., et al. (1996). Themes of agency and communion in significant autobiographical scenes. Journal of Personality, 64(2), 339-377.

McAdams, D., \& Janis, L. (2004). Narrative identity and narrative therapy. The handbook of narrative and psychotherapy: Practice, theory, and research, ed. L. Angus \& J. McLeod. Thousand Oaks: Sage Publications. 159-173.

McAdams, D., \& Guo, J. (2014). How shall I live? Constructing a life story in the college years. New directions for higher education, 166, 15-23.

Mori, A. (2015). Shinpen Mori Akira Chosakushû Vol. 1-8, edited by Tanaka T. Tokyo: Gakujutsu Shuppankai.

Mori, A. (1958). Minna no negau dôtoku kyôiku. Reimei Shobô.

Mori, A. (1959). Minna de susumeru dôtoku kyôiku. Reimei Shobô.

Saitô, H. (2003). Dôtoku kyôiku e no shinri ryôhô kara no apurôchi: Naratibu serapî no shiten o chûshin toshite. Tôkyô Jôhô Daigaku ronshû, 6(2), 79-87.

Sevilla, A. L. (2016). Education and empty relationality: Thoughts on education and the Kyoto School of Philosoophy. Journal of Philosophy of Education, 50(4), 639-654.

Sevilla, A. L. (2019). Aida (Inter-) als Narrativ: Eine Relektüre der Aidagara-Ethik von Watsuji Tetsurô. Polylog: Zeitschrift für interkulturelles Philosophieren, (41), 57-78.

Sevilla-Liu, A. (2019). Japanese philosophy of moral education: From Watsuji Tetsurô to Mori Akira. Budhi: A Journal of Ideas and Culture, 23.3, 95-142.

Sevilla-Liu, A. (2021). Mori Akira's education for self-awareness: Lessons from the Kyoto School for Mindful Education. Journal of Philosophy of Education (early view).

Standish, P., \& Saito, N. (2012). Education and the Kyoto School of Philosophy: Pedagogy for human transformation. Springer.

Smith, J. A., Flowers, P., \& Larkin, M. (2009). Interpretative phenomenological analysis: theory, method and research. Sage.

White, M., \& Epston, D. (1990). Narrative means to therapeutic ends. W.W. Norton \& Company.

White, M. (2005). Worshop notes. Retrieved from https://dulwichcentre.com.au/michael-white-workshopnotes.pdf

White, M. (2007). Maps of narrative practice. W. W. Norton \& Company.

Winslade, J., \& Monk, G. (2006). Narrative counseling in schools: Powerful \& Brief (2nd ed.). Corwin.

Publisher's Note Springer Nature remains neutral with regard to jurisdictional claims in published maps and institutional affiliations. 